\title{
P-ISSN 0126-1754
}

E-ISSN 2337-8751

Terakreditasi

LIPI

200/M/KPT/2020

Volume 20 Nomor 1, April 2021

\section{Berita}

Biologi

Jurnal IImu-ilmu Hayati

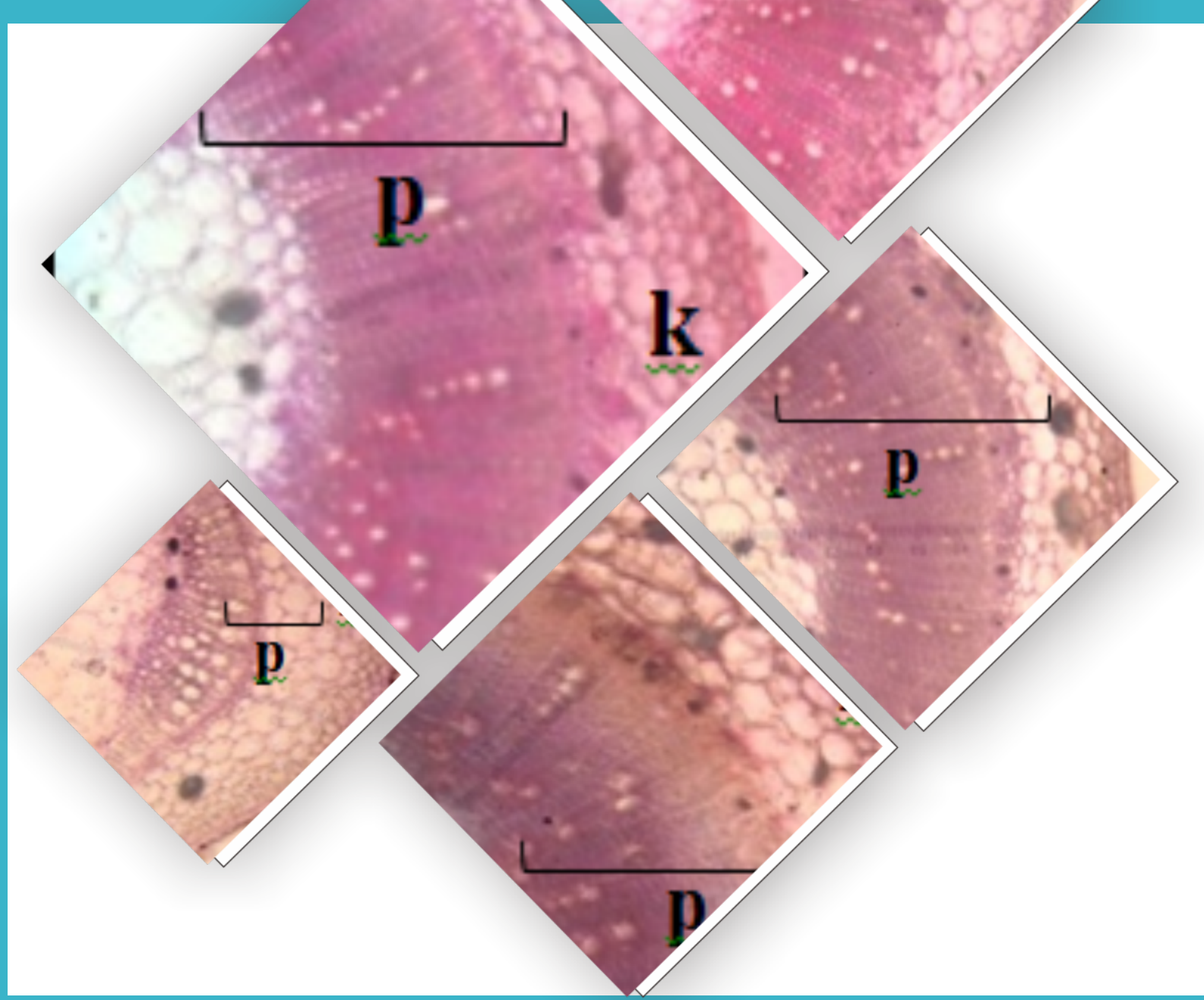




\title{
BERITA BIOLOGI
}

Vol. 20 No. 1 April 2021

Terakreditasi Berdasarkan Keputusan Direktur Jendral Penguatan Riset dan Pengembangan, Kemenristekdikti RI

200/M/KPT/2020

\section{Tim Redaksi (Editorial Team)}

Andria Agusta (Pemimpin Redaksi, Editor in Chief)

(Kimia Bahan Alam, Pusat Penelitian Kimia - LIPI)

Kartika Dewi (Redaksi Pelaksana, Managing Editor)

(Taksonomi Nematoda, Pusat Penelitian Biologi - LIPI)

Kusumadewi Sri Yulita

(Sistematika Molekuler Tumbuhan, Pusat Penelitian Biologi - LIPI)

Gono Semiadi

(Mammalogi, Pusat Penelitian Biologi - LIPI)

Atit Kanti

(Mikrobiologi, Pusat Penelitian Biologi - LIPI)

Siti Sundari

(Ekologi Lingkungan, Pusat Penelitian Biologi - LIPI)

Arif Nurkanto

(Mikrobiologi, Pusat Penelitian Biologi - LIPI)

Kartika Dewi

(Taksonomi Nematoda, Pusat Penelitian Biologi - LIPI)

Dwi Setyo Rini

(Biologi Molekuler Tumbuhan, Pusat Penelitian Biologi - LIPI)

\author{
Desain dan Layout (Design and Layout) \\ Liana Astuti
}

\section{Kesekretariatan (Secretary) \\ Nira Ariasari Z}

\author{
Alamat (Address) \\ Pusat Penelitian Biologi-LIPI \\ Kompleks Cibinong Science Center (CSC-LIPI) \\ Jalan Raya Jakarta-Bogor KM 46, \\ Cibinong 16911, Bogor-Indonesia \\ Telepon (021) 8765066 - 8765067 \\ Faksimili (021) 8765059 \\ Email: berita.biologi@mail.lipi.go.id \\ jurnalberitabiologi@yahoo.co.id \\ jurnalberitabiologi@gmail.com
}

Keterangan foto cover depan: Efek Cekaman Kromium Terhadap Profil Mikro-anatomi Cabai (Capsicum annuum L.)

(Notes of cover picture): $\quad$ Micro-anatomical of the stems structure of 400x magnification. (Halaman 107) 


\section{LIPI}

Volume 20 Nomor 1, April 2021

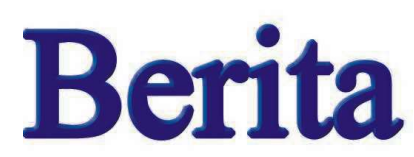

Biologi

Jurnal Ilmu-ilmu Hayati

\begin{tabular}{|l|l|l|l|l|l|}
\hline Berita Biologi & Vol. 20 & No. 1 & Hlm. 1 - 145 & Bogor, April 2021 & ISSN 0126-1754 \\
\hline
\end{tabular}




\section{Ucapan terima kasih kepada Mitra Bebestari nomor ini Volume 20 - April 2021}

Triwibowo Ambar Garjito, S.Si, M.Kes

(Dinamika transmisi penyakit tular vektor, taksonomi dan ekologi nyamuk, Balai Besar Penelitian dan Pengembangan Vektor \& Reservoir Penyakit, Badan Litbangkes, Kemenkes RI.)

Zuliyati Rohmah, S.Si., M.Si., Ph.D.

(Strukitur periembangan hewan invertebrata dan vertebrata)

Tri Handayani, M.Si.

(Bioekologi Vegetasi Laut/Makroalga, Pusat Penelitian Oseanografi LIPI)

Dr. Adi Santoso

(Bioteknologi, Pusat Penelitian Bioteknologi

Dra. Florentina Indah Windadri

(Taksonomi, Pusat Penelitian Biologi - LIPI

Dr. Wawan Sujawro

(Etnobiologi, Pusat Penelitian Biologi - LIPI

Arif Nurkanto

(Mikrobiologi, Pusat Penelitian Biologi - LIPI)

Heddy Julistiono

(Mikrobiologi, Pusat Penelitian Biologi - LIPI)

Yordan Khaedir, MD, PhD

(Histologi, Imunologi, Kanker Imunoterapi, Penyakit Infeksi, Fakultas Kedokteran UI

dr. Dwi Peni Kartika Sari, M.Si.

(Fakultas Kedokteran Universitas Airlangga)

Prof. Dr. Andria Agusta

(Kimia Bahan Alam, Pusat Penelitian Biologi LIPI)

Dr. Sunaryo

(Morfologi Tumbuhan, Pusat Penelitian Biologi - LIPI)

Dr. Nuril Hidayati Th.

(Fisiologi Tumbuhan, Pusat Penelitian Biologi - LIPI)

Dr. Achmad Dinoto M.Sc.

(Mikrobiologi Industri, Pusat Penelitian Biologi - LIPI)

Dr.Yuliar M.Eng.

(Mikrobiologi Lingkungan, Pusat Penelitian Biologi - LIPI)

Dr. Iwan Saskiawan

(Mikrobiologi Pangan, Pusat Penelitian Biologi - LIPI)

Dr. Indra Bachtiar

(Stem Cell and Cencer Institute), PT Kalbe Farma Tbk.) 


\title{
PROGRESS IMPLEMENTATION OF TARGET 9 OF GLOBAL STRATEGY FOR PLANT CONSERVATION CONDUCTED BY INDONESIAN BOTANIC GARDEN NETWORK
}

\author{
(Capaian Target 9 Strategi Global Konservasi Tumbuhan oleh Jaringan Kebun Raya Indo- \\ nesia)
}

Siti Fatimah Hanum**

Eka Karya" Bali Botanic Garden, Research Center for Plant Conservation and Botanic Garden - Indonesian Institute of Sciences, Candikuning, Baturiti, Tabanan, Bali 82191

ABSTRACT
Plant have been cultivated for a long time, they have been selected and bred by our ancestors for their nutritional qualities, flavor, produc-
tivity, storage ability and other valued traits. Crop Wild Relative (CWR) are often neglected because they have not been used for domesti-
cation. However, world population growth together with the potentially adverse impact of climate change on agricultural production, calls
for greater action to ensure global food security. Indonesian Botanic Garden already ratified Convention on Biodiversity (CBD). One of
the programs is the Global Strategy for Plant Conservation (GSPC). The GSPC vision is to stop the plant diversity loss through five objec-
tives and 16 targets for plant conservation to be achieved by 2020. The study was to identify the implementation of target 9 of GSPC by
Indonesian Botanic Garden Network. The result showed that there are four reason Indonesian Botanic Garden has participated in target 9
of GSPC, We also provided success stories from other botanic garden to encourage Indonesian Botanic Garden to conserve more Indone-
sian Crop Wild Relatives (CWR) whilst facilitating their use in crop improvement.
Keywords: Botanic garden, ex situ plant conservation, Global Strategy for Plant Conservation (GSPC), living collection, seed bank, target 9

\section{ABSTRAK}

Tanaman telah dibudidayakan sejak lama. Leluhur kita menyeleksi dan membudidayakan tanaman untuk kualitas nutrisi, rasa, produktivitas, daya simpan, dan sifat berharga lainnya. Kerabat tanaman liar pertanian sering diabaikan karena tidak digunakan untuk domestikasi. Namun seiring laju pertumbuhan populasi dunia dan pengaruh perubahan iklim yang merugikan bagi produksi pertanian mengharuskan adanya tindakan untuk menjamin ketahanan pangan. Kebun Raya Indonesia telah meratifikasi konvensi biodiversitas (CBD). Salah satu programnya adalah Strategi Global Konservasi Tumbuhan (GSPC). GSPC bertujuan untuk menghentikan proses kehilangan diversitas tanaman melalui lima sasaran dan 16 target konservasi tumbuhan yang akan dicapai pada tahun 2020. Penelitian ini bertujuan untuk mengidentifikasi capaian target 9 GSPC oleh Kebun Raya Indonesia. Hasilnya memperlihatkan bahwa Kebun Raya Indonesia berpartisipasi dalam pencapaian target 9 GSPC. Dalam tulisan ini kami juga memberikan contoh sukses dari kebun raya lain agar menginspirasi Kebun Raya Indonesia untuk mengonservasi kerabat tanaman liar pertanian Indonesia sambil memudahkan pemanfaatannya untuk perbaikan produk pertanian.

Kata kunci: kebun raya, Konservasi tumbuhan ex situ, Strategi global konservasi tumbuhan, koleksi hidup, bank biji, target 9

\section{INTRODUCTION}

Plants and animals have been used as a source of food and medicine (Ulian et al., 2019). Our ancestors have been treat plant from cultivation, selection and breeding for benefit reason such as nutritional qualities, flavor, productivity, storage ability and other valued traits (Schaal 2019). Crop wild relatives (CWR) are wild plant species that holding a common ancestor with cultivated crop plants of socio-economic value, such as human food, animal forage and fodder crops (Fielder et al., 2015). Crop wild relatives are considered rich sources of useful traits for crop improvement and generally underrepresented in genebanks, (van Treuren, 2020). However, CWR are often neglected because they have not been used for domestication. Whereas CWR is 
a genetic source for obtaining superior agricultural crops such as disease resistance, drought resistance, and more yields. Information about CWR is mostly compiled by traditional communities who live in the village and must be preserved.

Among the Southeast Asian countries, Indonesia was estimated to contain the highest number of vascular plants around 30.000- 40.000 plants (Butler, 2016; Widjaja et al., 2014). The origin of cultivated plant in South East Asia is debatable, but based on latitudinal zones in eastern Asia in respect to cultivated plants divided into 4 namely (1). The Northern China Belt, (2) the Southern China Belt, (3) the Southern Asia Belt and (4) the Southern Islands Belt. While Indonesia belong to the Southern Islands Belt. The origin of cultivated plant from Southern Islands Belt consist of Artocarpus altilis, Artocarpus integra, Averrhoa carambola, Averrhoa bilimbi, Citrus aurantifolia, Garcinia mangostana, Nephelium lappaceum, Lansium domestic, Durio zibethibus, Terminalia catappa, Eugenia javanica, Musa x paradisiaca, Saccharum officinarum, Myristica fragrans, Eugenia caryophyllus. (Hui lin, 1970). Specifically, Kusmana and Hikmat (2015) mention Indonesia also one center of Vavilov for banana (Musa spp), Nutmeg (Myristica fragrans), clove (Syzygium aromaticum), Durian (Durio spp.) and Rambutan (Nephelium spp.).

However, Indonesia also has the highest number of global priorities CWR (Rahman et al., 2019). Meanwhile, 18.700 plant species are predicted to be endemic in Indonesia. Unfortunately, only $1 / 3$ of the total number of Indonesian plants that have been identified and documented (Surya et al., 2013). Furthermore, Indonesia is 1 of 25 biodiversity hotspots in the world, an area with high endemic species and threatened by habitat loss (Myers et al., 2000). On the other hand, the current world population growth together with the potentially adverse impact of climate change on agricultural production, calls for greater action to ensure global food security (Ulian et al., 2019). Besides that, the use of superior varietas agricultural crop without conserve landrace increase plant genetic erosion (Widjaja et al., 2014).

Since has the highest number of CWR in Indo- nesia, Indonesia has not yet had the list of CWR that has priority to conserve (Rahman et al., 2019). At national level the Ministry of Agriculture have determined 32 prioritized crop species comprise of 7 food crop (rice, soybean, maize, cassava, sweet potato, mungbean, and peanut), 10 horticultural species (chilli pepper, paprika, shallot, potato, mango, citrus, banana, durian, mangosteen and salacca), and 15 estate crop species (rubber, coconut, oil palm, coffee, cacao, cashew nut, pepper clove, tea, jatropa, pecan, sugarcane, cotton, tobacco and patcheoli (Sabran, 2016). Therefore, Rahman et al. (2019) proposes 234 taxa as priority for conservation. This priority taxa divided into three group comprised of ninety-five priority taxa that are important at the national and global level such as wild relatives of rice, banana, mango, breadfruit, sugarcane, taro, coconut, sweet potato, melon, sorghum, citrus, aubergine), 69 taxa are important at the national and regional level (such as wild relatives of tropical fruits and sugar crops) and 70 taxa are important at global level only such as wild relatives of yam, figs, and raspberry.

Meanwhile, the effort to safeguard Indonesian plants must be based on the Global Strategy for Plant Conservation (GSPC), because Indonesia has ratified Convention on Biodiversity (CBD). The GSPC vision is to halt the loss of the plant diversity through five objectives and 16 targets for plant conservation to be achieved by 2020 (Convention on Biological Diversity 2016; Hird and Kramer 2013). Botanic gardens address many of the GSPC targets (Jackson and Sutherland 2000). Indonesian Botanic Garden (IBG) can participate in at least 13 targets but unfortunately, there has been no progress on target 6, 9 and 12 (Widyatmoko and Rosniati 2017). This study focusses on the progress implementation target 9 of GSPC by Indonesian botanic garden network and recommendation to achieve this target in the future

\section{MATERIAL AND METHODS}

To assess how existing plant conservation projects are addressing target 9 GSPC in Indonesia, we compile plant collection data from Bogor (2019), Cibodas (2019), Purwodadi (2012) and Eka Karya Botanic Garden (2020). One of food and agriculture 
priority commodity is banana, yam and taro. Beside that we also do study literature to give a comprehensive information about Target 9 GSPC achievement.

\author{
RESULTS \\ Progress Implementation of Target 9 GSPC by \\ Indonesian Botanic Garden (IBG). \\ Indonesian Botanic Garden has significant \\ progress to achieve the target through GSPC (Table \\ 1.). Unfortunately, target 9 not yet reported \\ (Widyatmoko and Rosniati 2017
}

Tabel 1. Indonesian botanic garden result to achieve Global Strategy for Plant Conservation Target 2010-2020 (Widyatmoko and Rosniati 2017). (Capaian target strategi global konservasi tumbuhan tahun 20102020 oleh Kebun Raya Indonesia (Widyatmoko dan Rosniati, 2017))

GSPC Target 2010-2020 (Target GSPC tahun 2010-2020)
Indonesian Botanic Garden result

(Capaian Kebun Raya Indonesia)
Objective I Plant diversity is well understood,documented and recognize (Tujuan 1. Keanekaragaman tumbuhan dapat dipahami, didokumetasikan dan diakui nilai pentinya)

Target 1. An online flora of all known plants (target 1 . Tersedianya online flora untuk tumbuhan yang sudah teridentifikasi)

Target 2. An assessment of the conservation status of all known plant species, as far as possible to guide conservation action (Target 2. Penilaian status konservasi tumbuhan yang sudah diketahui, lebih jauh sebagai panduan kegiatan konservasi)

Target 3. Information, research and associated outputs and methods necessary to implement the strategy developed and shared (Target 3. Informasi, penelitian dan keluaran serta metode terkait yang diperlukan untuk mengimplementasikan strategi yang dikembangkan dan dibagikan)

Objective II. Plant diversity is urgently and effectively conserved. (Tujuan II. Keanekaragaman tumbuhan sangat penting dan dikonservasi secara efektif)

Target 4 . At least $15 \%$ of ecological region or vegetation type secured through effective management and/or restoration. (Target 4. Setidaknya 15\% Kawasan ekologi atau tipe vegetasi dijamin melalui pengelolaan dan/ atau restorasi yang efektif)

Target 5. At least $75 \%$ of the most important areas for plant diversity of each ecological region protected with effective management in place for conserving plants and their genetic diversity. (Target 5. Setidaknyaa 75\% dari kawasan terpenting untuk keanekaragaman tumbuhan di setiap kawasan ekologi dilindungi dengan pengelolaan efektif untuk melestarikan tumbuhan dan keanekaragaman genetiknya)
Significant progress

(kemajuan yang signifikan)

Little progress

(sedikit kemajuan)

Little progress

(sedikit kemajuan)

Significant progress

(kemajuan yang signifikan)

Significant progress

(kemajuan yang signifikan) 
Tabel 1. Indonesian botanic garden result to achieve Global Strategy for Plant Conservation Target 2010-2020 (Widyatmoko and Rosniati 2017). (Capaian target strategi global konservasi tumbuhan tahun 2010 2020 oleh Kebun Raya Indonesia (Widyatmoko dan Rosniati, 2017)) (lanjutan).

\begin{tabular}{|c|c|}
\hline GSPC Target 2010-2020 (Target GSPC tahun 2010-2020) & $\begin{array}{l}\text { Indonesian Botanic Garden result } \\
\text { (Capaian Kebun Raya Indonesia) }\end{array}$ \\
\hline $\begin{array}{l}\text { Target } 6 . \text { At least } 75 \% \text { of production lands in each sector } \\
\text { managed sustainably consistent with the conservation of plant } \\
\text { diversity (Target } 6 . \text { Setidaknya } 75 \% \text { lahan produksi di setiap } \\
\text { sector dikelola secara lestari sesuai dengan Konservasi } \\
\text { keanekaragaman tumbuhan) }\end{array}$ & $\begin{array}{l}\text { No progress } \\
\text { (Tidak ada perkembangan) }\end{array}$ \\
\hline $\begin{array}{l}\text { Target } 7 \text {. At least } 75 \% \text { of known threatened plant species } \\
\text { conserved in situ (Target } 7 \text {. Sedikitnya } 75 \% \text { tumbuhan teran- } \\
\text { cam punah dikonservasi secara in situ) }\end{array}$ & $\begin{array}{l}\text { Little progress } \\
\text { (sedikit kemajuan) }\end{array}$ \\
\hline $\begin{array}{l}\text { Target } 8 \text {. At least } 75 \% \text { of threatened plant species in ex } \\
\text { situ collections, preferably in the country of origin, and at least } \\
20 \% \text { available for recovery and restoration program (Target } 8 \text {. } \\
\text { Sedikitnya } 75 \% \text { tumbuhan terancam dikoleski secara ex situ, } \\
\text { diutamakan di negara asalnya dan sedikitnya } 20 \% \text { sudah } \\
\text { tersedia untuk program pemulihan dan restorasi) }\end{array}$ & $\begin{array}{l}\text { Significant progress } \\
\text { (kemajuan yang signifikan) }\end{array}$ \\
\hline $\begin{array}{l}\text { Target } 9.70 \% \text { of the genetic diversity of crops including } \\
\text { their wild relative and other socio-economically valuable plant } \\
\text { species conserved, while respecting, preserving, and maintain- } \\
\text { ing associated indigenous and local knowledge. ( } 70 \% \text { dari } \\
\text { keanekargaman tumbuhan termasuk kerabat liar dan spesies } \\
\text { tanaman bernilai sosial ekonomi lainnya dilestarikan dengan } \\
\text { tetap menghormati, melestarikan, dan memelihara kearifan } \\
\text { dan pengetahuan local) }\end{array}$ & $\begin{array}{l}\text { No progress } \\
\text { (Tidak ada perkembangan) }\end{array}$ \\
\hline $\begin{array}{l}\text { Target } 10 \text {. Effective management plans in place to pre- } \\
\text { vent new biological invasions and to manage important areas } \\
\text { for plant diversity that are invaded. (Target 10. Tersedia ren- } \\
\text { cana pengelolaan yang efektif untuk mencegah invasi biologis } \\
\text { baru dan untuk mengelola kawasan penting bagi keane- } \\
\text { karagaman tumbuhan yang sudah diinvasi) }\end{array}$ & $\begin{array}{l}\text { Little progress } \\
\text { (sedikit kemajuan) }\end{array}$ \\
\hline $\begin{array}{l}\text { Objective III. Plant diversity is used in a sustainable and } \\
\text { equitable manner (Tujuan III. Keanekaragaman tumbuhan } \\
\text { dimanfaatkan secara berkelanjutan dan adil) } \\
\text { Target } 11 \text {. No species of flora endangered by interna- } \\
\text { tional trade. (Target 11. Tidak ada spesies tumbuhan terancam } \\
\text { punah dalam perdagangan internasional) }\end{array}$ & $\begin{array}{l}\text { Little progress } \\
\text { (sedikit kemajuan) }\end{array}$ \\
\hline $\begin{array}{l}\text { Target } 12.30 \% \text { of plant-based products derivated from } \\
\text { sources that are sustainably managed. (Target } 12.30 \% \text { produk } \\
\text { nabati berasal dari sumber yang dikelola secara berkelanju- } \\
\text { tan) }\end{array}$ & $\begin{array}{l}\text { No progress } \\
\text { (Tidak ada perkembangan) }\end{array}$ \\
\hline
\end{tabular}


Tabel 1. Indonesian botanic garden result to achieve Global Strategy for Plant Conservation Target 2010-2020 (Widyatmoko and Rosniati 2017). (Capaian target strategi global konservasi tumbuhan tahun 20102020 oleh Kebun Raya Indonesia (Widyatmoko dan Rosniati, 2017)) (lanjutan).

\begin{tabular}{|c|c|}
\hline GSPC Target 2010-2020 (Target GSPC tahun 2010-2020) & $\begin{array}{l}\text { Indonesian Botanic Garden result } \\
\text { (Capaian Kebun Raya Indonesia) }\end{array}$ \\
\hline $\begin{array}{l}\text { Target 13. Indigenous and local knowledge innovations } \\
\text { and practices associated with plant resources maintained or } \\
\text { increased as appropriate to support customary use, sustainable } \\
\text { livelihoods, local food security, and health care. (Target } 13 \text {. } \\
\text { Inovasi dan praktek kearifan dan pengetahuan lokal yang } \\
\text { terkait dengan sumber daya tumbuhan yang dipertahankan } \\
\text { atau ditingkatkan sesuai kebutuhan yang mendukung peng- } \\
\text { gunaan secara adat, mata pencaharian berkelanjutan, } \\
\text { ketahanan pangan lokal dan perawatan kesehatan) }\end{array}$ & $\begin{array}{l}\text { Little progress } \\
\text { (sedikit kemajuan) }\end{array}$ \\
\hline $\begin{array}{l}\text { Objective IV. Educational and awareness about plant } \\
\text { diversity, its role in sustainable livelihoods, and importance to } \\
\text { all life on earth is promoted. (Tujuan IV. Pendidikan dan kesa- } \\
\text { daran tentang keanekaragaman tumbuhan, perannya dalam } \\
\text { mata pencaharian berkelanjutan dan pentingnya untuk selu- } \\
\text { ruh kehidupan di bumi dipromosikan ) } \\
\text { Target 14. The importance of plant diversity and the need } \\
\text { for its conservation incorporated into communication, educa- } \\
\text { tional and public-awareness programs. (Target 14. Pentingnya } \\
\text { keanekaragaman tumbuhan dan perlunya konservasi dimasuk- } \\
\text { kan dalam program komunikasi, Pendidikan dan penyadaran } \\
\text { publik) }\end{array}$ & $\begin{array}{l}\text { Significant progress } \\
\text { (kemajuan yang signifikan) }\end{array}$ \\
\hline $\begin{array}{l}\text { Objective V. The capactities and public engagement } \\
\text { necessary to implement the strategy have been developed. } \\
\text { (Tujuan V. Kapasitas dan keterlibatan public diperlukan untuk } \\
\text { mengimplementasikan strategi yang telah dikembangkan) } \\
\text { Target } 15 \text {. The number of trained people working with } \\
\text { appropriate facilities in plant conservation increased.(Target } \\
\text { 15. Jumlah orang terlatih yang bekerja dengan fasilitas yang } \\
\text { sesuai dalam konservasi tumbuhan meningkat) }\end{array}$ & $\begin{array}{l}\text { Little progress } \\
\text { (sedikit kemajuan) }\end{array}$ \\
\hline $\begin{array}{l}\text { Target } 16 \text {. Network for plant conservation activities es- } \\
\text { tablished or strengthened at national, regional and interna- } \\
\text { tional levels. (Target 16. Jejaring untuk kegiatan Konservasi } \\
\text { tumbuhan dibentuk dan diperkuat di tingkat nasional, regional } \\
\text { dan internasional) }\end{array}$ & $\begin{array}{l}\text { Significant progress } \\
\text { (kemajuan yang signifikan) }\end{array}$ \\
\hline
\end{tabular}


Tabel 2. Indonesian Botanic Garden result to achieve Target 9 Global Strategy for Plant Conservation on Food priority (Banana, Yam and Taro). (Capaian target 9 strategi global Konservasi tumbuhan untuk prioritas pangan (pisang, ubi, dan talas) oleh Kebun Raya Indonesia)

\begin{tabular}{|c|c|c|c|}
\hline $\begin{array}{c}\text { Indonesian Botanic } \\
\text { Garden (Kebun Raya } \\
\text { Indonesia) } \\
\end{array}$ & $\begin{array}{l}\text { Wild banana species } \\
\text { (Spesies liar pisang) }\end{array}$ & $\begin{array}{l}\text { Dioscorea species } \\
\text { (Spesies Dioscorea) }\end{array}$ & $\begin{array}{l}\text { Colocasia species } \\
\text { (Spesies Colocasia) }\end{array}$ \\
\hline $\begin{array}{l}\text { Bogor Botanic Garden } \\
\text { (Ariati et al., 2019) }\end{array}$ & $\begin{array}{l}\text { Musa acuminata Colla } \\
\text { Musa brachycarpa Baker } \\
\text { Musa laterita } \text { E.E. Chees- } \\
\text { man } \\
\text { Musa ornata } \\
\text { Musa paradisiaca } \\
\text { Musa salaccensis Zoll. Ex } \\
\text { Baker } \\
\text { Musa sanguinea Hook.f. } \\
\text { Musa velutina } \text { H. } \\
\text { wendl.\&Drude } \\
\text { Musa } \text { sp }\end{array}$ & $\begin{array}{l}\text { Dioscorea alata } \mathrm{L} \\
\text { Dioscorea bulbifera } \mathrm{L} . \\
\text { Dioscorea esculenta } \\
\text { (Lour) Burkill } \\
\text { Dioscorea hispida Dennst } \\
\text { Dioscorea nummularia } \\
\text { Lam } \\
\text { Dioscorea retusa Mast. } \\
\text { Dioscorea sansibarensis } \\
\text { Pax } \\
\text { Dioscorea } \mathrm{sp} .\end{array}$ & $\begin{array}{l}\text { Colocasia esculenta } \\
\text { (L.) Schott }\end{array}$ \\
\hline $\begin{array}{l}\text { Cibodas Botanic Garden } \\
\text { (Sujarwo et al., } 2019\end{array}$ & $\begin{array}{l}\text { Musa acuminata Colla } \\
\text { Musa banksia F. Muell } \\
\text { Musa zebrina van Houffe } \\
\text { ex Planch } \\
\text { Musa } \text { sp. }\end{array}$ & - & Colocasia spp. \\
\hline $\begin{array}{l}\text { Purwodadi Botanic Gar- } \\
\text { den (Narko et al., 2012) }\end{array}$ & $\begin{array}{l}\text { Musa acuminata Colla } \\
\text { Musa balbisiana Colla }\end{array}$ & $\begin{array}{l}\text { Dioscorea alata } \mathrm{L} \\
\text { Dioscorea esculenta } \\
\text { (Lour.)Burkill } \\
\text { Dioscorea hispida } \\
\text { Dennst } \\
\text { Dioscorea pentaphylla } \\
\text { (Lour) Burkill }\end{array}$ & Colocasia sp. \\
\hline $\begin{array}{l}\text { Bali Botanic Garden } \\
\text { (Plant Registration Unit, } \\
\text { 2020) }\end{array}$ & $\begin{array}{l}\text { Ensete superbum (Roxb.) } \\
\text { Cheesman } \\
\text { Musa velutina } \mathrm{H} \text {. Wendl } \\
\text { \& Drude } \\
\text { Musa balbisiana Colla } \\
\text { Musa } \text { sp. }\end{array}$ & $\begin{array}{l}\text { Dioscorea alata L } \\
\text { Dioscorea bulbifera L. } \\
\text { Dioscorea esculenta } \\
\text { (Lour.) Burkill } \\
\text { Dioscorea hispida Denn } \\
\text { Dioscorea pentaphylla } \\
\text { (Lour) Burkill } \\
\text { Diosocrea } \mathrm{sp} .\end{array}$ & $\begin{array}{l}\text { Colocasia esculenta } \\
\text { Colocasia gigantea } \\
\text { (Blume) } \\
\text { Colocasia } \text { sp. }\end{array}$ \\
\hline
\end{tabular}

Since this target is not belong as the main activity of Indonesian Botanic Garden, but in fact, IBG show activity related to the implementation target 9 of GSPC. First, the main research of Indonesian Botanic Garden divide into tree cluster consist of Conservation, Domestication and Reintroduction. Regarding to this cluster research, some Indonesian botanic garden also conserve plant that has food function (Table 2) such as Purwodadi Botanic Garden collect many different types of Dioscorea spp, Musaceae and Yam wild relatives as their living collection (Sharrock 2013; Trimanto and Hapsari 2015). However, in 90's Purwodadi Botanic Garden was the leading botanical garden of Musaceae collection in South East Asia (Hapsari, 2010). Purwodadi Botanic Garden has banana collection consist of 316 number collection, 114 cultivar and, 4 type parental for cross breeding. Musa acuminata and Musa balbisiana (pisang kluthuk wulung) are wild species that used as parental for cross breeding in Indonesia. Meanwhile, Bogor Botanic Garden also has wild banana species collection. Among them are M.acuminata var malaccensis, M. balbisiana var liukiuensis, M. acuminate 
var halabanensis, M.acuminata var zebrina, dan M. acuminata var nakaii (Widjaja et al., 2014). Therefore, Bali Botanic Garden also has wild banana species collection comprise of Musa balbisiana var brachycarpa (Ariati et al., 2019) and Cibodas Botanic Garden also has one Musa balbisiana var sumatrana (CBG registration, 2019). IBG also conduct Breeding activities limited in their scope and intensities (Sabran, 2016). Lestari and Surya (2016) said that Bogor and Cibodas Botanic Garden have local fruit germplasm and plant breeding program, at least eight genera, consist of Persea American,
Baccaurea spp., Garcinia spp., Nephelium spp., Durio sp., Mangifera spp., Artocarpus spp., and Willughbela spp.

Second, there is a new botanic garden have been developed in some Indonesian region. Until recent times, Indonesia has 43 botanic gardens consist of five botanic gardens under the Indonesian Institute of Sciences (LIPI) while others are managed by local governments and universities. This botanic garden location spreading across 23 provinces. (Table 3.) (Bidang Pengembangan Kawasan Kebun Raya, 2019).

Table 3. Indonesian Botanic Garden (Bidang Pengembangangan Kawasan Kebun Raya, 2019; Widyatmoko and Risna, 2017 ). (Kebun Raya Indonesia (Bidang Pengembangan Kawasan Kebun Raya, 2019; Widyatmoko dan Risna, 2017))

\begin{tabular}{|c|c|c|c|}
\hline No & $\begin{array}{l}\text { Botanic garden } \\
\text { (Kebun Raya) }\end{array}$ & $\begin{array}{l}\text { Collection theme/focus } \\
\text { (tema koleksi/fokus) }\end{array}$ & Province (Propinsi) \\
\hline 1 & Bogor & $\begin{array}{l}\text { Humid lowland and plants } \\
\text { (Tumbuhan dataran rendah beriklim } \\
\text { basah) }\end{array}$ & West Java (Jawa Barat) \\
\hline 2 & "Eka Karya" Bali & $\begin{array}{l}\text { Dry highland plants } \\
\text { (Tumbuhan dataran tinggi kering) }\end{array}$ & Bali \\
\hline 3 & Massenrempulu Enrekang & $\begin{array}{l}\text { Wallaceae region flora } \\
\text { (Tumbuhan kawasan wallaceae) }\end{array}$ & $\begin{array}{l}\text { South of Sulawesi } \\
\text { (Sulawesi Selatan) }\end{array}$ \\
\hline 4 & Kuningan & $\begin{array}{l}\text { Rocky and Mount Ceremai plants } \\
\text { (Tumbuhan daerah berbatu dan } \\
\text { gunung ceremai) }\end{array}$ & West Java (Jawa Barat) \\
\hline 5 & Cibodas & $\begin{array}{l}\text { Humid highland plants } \\
\text { (Tumbuhan dataran tinggi) }\end{array}$ & West Java (Jawa Barat) \\
\hline 6 & Purwodadi & $\begin{array}{l}\text { Dry lowland plants (Tumbuhan data- } \\
\text { ran rendah) }\end{array}$ & East Java (Jawa Timur) \\
\hline 7 & Banua & $\begin{array}{l}\text { Kalimantan medicinal plants } \\
\text { (Tumbuhan obat Kalimantan) }\end{array}$ & $\begin{array}{l}\text { South Kalimantan } \\
\text { (Kalimantan Selatan) }\end{array}$ \\
\hline 8 & Cibinong & $\begin{array}{l}\text { Indonesian bioregion plants } \\
\text { (Tumbuhan Indonesia berdasarkan } \\
\text { bioregion) }\end{array}$ & West Java (Jawa Barat) \\
\hline 9 & Balikpapan & $\begin{array}{l}\text { Indonesian timber plants (Tumbuhan } \\
\text { kayu Indonesia) }\end{array}$ & $\begin{array}{l}\text { East Kalimantan } \\
\text { (Kalimantan Timur) }\end{array}$ \\
\hline 10 & Baturraden & $\begin{array}{l}\text { Java mountainous flora (Tumbuhan } \\
\text { pegunungan Jawa) }\end{array}$ & $\begin{array}{l}\text { Central of Java (Jawa Ten- } \\
\text { gah) }\end{array}$ \\
\hline 11 & Wamena & $\begin{array}{l}\text { Central papua mountainous flora } \\
\text { (Tumbuhan pegunungan tengah } \\
\text { Papua) }\end{array}$ & Papua \\
\hline 12 & Liwa & $\begin{array}{l}\text { Indonesian ornamental plants } \\
\text { (Tumbuhan hias Indonesia) }\end{array}$ & Lampung \\
\hline
\end{tabular}


Table 3. Indonesian Botanic Garden (Bidang Pengembangangan Kawasan Kebun Raya, 2019; Widyatmoko and Risna, 2017 ). (Kebun Raya Indonesia (Bidang Pengembangan Kawasan Kebun Raya, 2019; Widyatmoko dan Risna, 2017)) (lanjutan)

\begin{tabular}{|c|c|c|c|}
\hline No & $\begin{array}{l}\text { Botanic garden } \\
\text { (Kebun Raya) }\end{array}$ & $\begin{array}{l}\text { Collection theme/focus } \\
\text { (tema koleksi/fokus) }\end{array}$ & Province (Propinsi) \\
\hline 13 & Katingan & $\begin{array}{l}\text { Indonesian fruit plants } \\
\text { (Tumbuhan buah Indonesia) }\end{array}$ & $\begin{array}{l}\text { Central of Kalimantan } \\
\text { (Kalimantan Tengah) }\end{array}$ \\
\hline 14 & Sriwijaya & $\begin{array}{l}\text { Sumatera medicinal and wetland } \\
\text { plants (Tumbuhan obat dan lahan } \\
\text { basah Sumatera) }\end{array}$ & $\begin{array}{l}\text { South Sumatera (Sumatera } \\
\text { Selatan) }\end{array}$ \\
\hline 15 & Sambas & $\begin{array}{l}\text { Kalimantan riparian flora (Tumbuhan } \\
\text { riparian Kalimantan) }\end{array}$ & $\begin{array}{l}\text { West Kalimantan } \\
\text { (Kalimantan Barat) }\end{array}$ \\
\hline 16 & Bukit Sari & $\begin{array}{l}\text { Sumatera lowland flora } \\
\text { (Tumbuhan dataran rendah Su- } \\
\text { matera) }\end{array}$ & Jambi \\
\hline 17 & Samosir & $\begin{array}{l}\text { North Sumatera highland flora } \\
\text { (Tumbuhan dataran tinggi sumatera } \\
\text { utara) }\end{array}$ & $\begin{array}{l}\text { North Sumatera (Sumatera } \\
\text { Utara) }\end{array}$ \\
\hline 18 & Lombok & $\begin{array}{l}\text { Lesser sunda plants (Tumbuhan kepu- } \\
\text { lauan sunda kecil) }\end{array}$ & $\begin{array}{l}\text { West Nusa Tenggara } \\
\text { (Nusa Tenggara Barat) }\end{array}$ \\
\hline 19 & "jompie" Pare-Pare & $\begin{array}{l}\text { Coastal wallacea flora (Tumbuhan } \\
\text { Kawasan pesisir wallacea) }\end{array}$ & $\begin{array}{l}\text { South Sulawesi (Sulawesi } \\
\text { Selatan) }\end{array}$ \\
\hline 20 & Pucak & $\begin{array}{l}\text { Economical value plants (Tumbuhan } \\
\text { bernilai ekonomi) }\end{array}$ & $\begin{array}{l}\text { South Sulawesi (Sulawesi } \\
\text { Selatan) }\end{array}$ \\
\hline 21 & Batam & $\begin{array}{l}\text { Small islands flora (Tumbuhan pulau- } \\
\text { pulau kecil Indonesia) }\end{array}$ & $\begin{array}{l}\text { Riau island (Kepulauan } \\
\text { Riau) }\end{array}$ \\
\hline 22 & Danau Lait & $\begin{array}{l}\text { Equatorial region plants (Tumbuhan } \\
\text { Kawasan ekuator) }\end{array}$ & $\begin{array}{l}\text { West Kalimantan } \\
\text { (Kalimantan Barat) }\end{array}$ \\
\hline 23 & Kendari & $\begin{array}{l}\text { Ultrabasic flora (Tumbuhan Ultra } \\
\text { Basic) }\end{array}$ & $\begin{array}{l}\text { South east Sulawesi } \\
\text { (Sulawesi Tenggara) }\end{array}$ \\
\hline 24 & Minahasa & $\begin{array}{l}\text { Highland wallaceae region flora } \\
\text { (Tumbuhan dataran tinggi wallaceae) }\end{array}$ & $\begin{array}{l}\text { North Sulawesi } \\
\text { (Sulawesi Utara) }\end{array}$ \\
\hline 25 & Solok & $\begin{array}{l}\text { Spice plants (Tumbuhan rempah In- } \\
\text { donesia) }\end{array}$ & $\begin{array}{l}\text { West Sumatera } \\
\text { (Sumatera Barat) }\end{array}$ \\
\hline 26 & Megawati Soekarnoputri & $\begin{array}{l}\text { Lowland wallacea regional plants } \\
\text { (Tumbuhan pamah Kawasan walla- } \\
\text { ceae) }\end{array}$ & $\begin{array}{l}\text { North Sulawesi } \\
\text { (Sulawesi Utara) }\end{array}$ \\
\hline 27 & Pelalawan & $\begin{array}{l}\text { Sumatran peat swamp plants } \\
\text { (tumbuhan rawa gambut Sumatera) }\end{array}$ & Riau \\
\hline 28 & Balangan & $\begin{array}{l}\text { Balangan native plant and Kaliman- } \\
\text { tan lowland forest (Tumbuhan asli } \\
\text { Balangan dan hutan pamah Kaliman- } \\
\tan \text { ) }\end{array}$ & $\begin{array}{l}\text { South Kalimantan } \\
\text { (Kalimantan Selatan) }\end{array}$ \\
\hline
\end{tabular}


Table 3. Indonesian Botanic Garden (Bidang Pengembangangan Kawasan Kebun Raya, 2019; Widyatmoko and Risna, 2017 ). (Kebun Raya Indonesia (Bidang Pengembangan Kawasan Kebun Raya, 2019; Widyatmoko dan Risna, 2017)) (lanjutan)

\begin{tabular}{|c|c|c|c|}
\hline No & $\begin{array}{l}\text { Botanic garden } \\
\text { (Kebun Raya) }\end{array}$ & $\begin{array}{l}\text { Collection theme/focus } \\
\text { (tema koleksi/fokus) }\end{array}$ & Province (Propinsi) \\
\hline 29 & Gianyar & $\begin{array}{l}\text { Gianyar native plant, Balinese me- } \\
\text { dicinal and ceremonial plant } \\
\text { (Tumbuhan asli Gianyar, upacara } \\
\text { adat dan tumbuhan obat Bali) }\end{array}$ & Bali \\
\hline 30 & Indrokilo Boyolali & $\begin{array}{l}\text { Eastern Java lowland rainforest } \\
\text { (Tumbuhan hutan hujan dataran ren- } \\
\text { dah Jawa bagian timur) }\end{array}$ & $\begin{array}{l}\text { Central Java (Jawa Ten- } \\
\text { gah) }\end{array}$ \\
\hline 31 & Institut Teknologi Sumatera & $\begin{array}{l}\text { Sumatera lowland forest (hutan hujan } \\
\text { pamah Sumatera) }\end{array}$ & Lampung \\
\hline 32 & Jagatnatha, Jembrana & $\begin{array}{l}\text { Balinese medicinal and ceremonial } \\
\text { plant (Tumbuhan usada dan upacara } \\
\text { adat Bali) }\end{array}$ & Bali \\
\hline 33 & Rimbe Mambang & $\begin{array}{l}\text { Bangka native plant and lowland for- } \\
\text { est (Tumbuhan asli Bangka dan hutan } \\
\text { pamah Sumatera) }\end{array}$ & $\begin{array}{l}\text { Bangka Belitung Island } \\
\text { (Kepulauan Bangka Beli- } \\
\text { tung) }\end{array}$ \\
\hline 34 & Sampit & $\begin{array}{l}\text { Heath forest (Tumbuhan hutan keran- } \\
\text { gas) }\end{array}$ & $\begin{array}{l}\text { West Kalimantan } \\
\text { (Kalimantan Barat) }\end{array}$ \\
\hline 35 & Sipirok Tapanuli Selatan & $\begin{array}{l}\text { Sumatera transitional lowland forest } \\
\text { to mountain rainforest (Tumbuhan } \\
\text { pada zona peralihan antara hutan } \\
\text { hujan pamah dan hutan hujan } \\
\text { pegunungan Sumatera) }\end{array}$ & $\begin{array}{l}\text { North Sumatera } \\
\text { (Sumatera Utara) }\end{array}$ \\
\hline 36 & Tanjung Puri Tabalong & $\begin{array}{l}\text { Kalimantan } \quad \text { lowland forest } \\
\text { (Tumbuhan hutan pamah Kaliman- } \\
\text { tan) }\end{array}$ & $\begin{array}{l}\text { South Kalimantan } \\
\text { (Kalimantan Selatan) }\end{array}$ \\
\hline 37 & Tebit gadong Beltung Timur & $\begin{array}{l}\text { Bangka Belitung heath forest } \\
\text { (Tumbuhan hutan kerangas Bangka } \\
\text { Belitung) }\end{array}$ & $\begin{array}{l}\text { Bangka Belitung island } \\
\text { (Kepulauan Bangka Beli- } \\
\text { tung) }\end{array}$ \\
\hline 38 & $\begin{array}{l}\text { Uniersitas Halu Oleo } \\
\text { Kendari }\end{array}$ & $\begin{array}{l}\text { Sulawesi endemic plants (Tumbuhan } \\
\text { endemik Sulawesi) }\end{array}$ & $\begin{array}{l}\text { South East Sulawesi } \\
\text { (Sulawesi tenggara) }\end{array}$ \\
\hline 39 & Sigi & $\begin{array}{l}\text { Sulawesi monsoon forest (Tumbuhan } \\
\text { hutan gugur daun Sulawesi) }\end{array}$ & $\begin{array}{l}\text { Central Sulawesi } \\
\text { (Sulawesi tengah) }\end{array}$ \\
\hline 40 & Walaboba Ngada & $\begin{array}{l}\text { Mountain lesser sunda plants } \\
\text { (Tumbuhan pegunungan kepulauan } \\
\text { Sunda kecil) }\end{array}$ & $\begin{array}{l}\text { East Nusa Tenggara (Nusa } \\
\text { Tenggara Timur) }\end{array}$ \\
\hline 41 & Belingkang Bangli & $\begin{array}{l}\text { Mountain Balinese ceremonial plants } \\
\text { (Tumbuhan upacara hindu Kawasan } \\
\text { pegunungan Bali) }\end{array}$ & Bali \\
\hline 42 & Gunung Tidar Magelang & $\begin{array}{l}\text { Ornamental plant on Java lowland } \\
\text { forest (tumbuhan hias pada hutan } \\
\text { hujan dataran rendah jawa bagian } \\
\text { timur) }\end{array}$ & $\begin{array}{l}\text { Central Java (Jawa Ten- } \\
\text { gah) }\end{array}$ \\
\hline 43 & Mangrove Surabaya & $\begin{array}{l}\text { Mangrove plants (tumbuhan man- } \\
\text { grove) }\end{array}$ & East Java (Jawa Timur) \\
\hline
\end{tabular}


This new botanic garden has a thematical garden that focuses on the rare local excellent product such as Baturaden botanic garden focus on medicinal plants and liana; Katingan botanic garden focus on tropical fruit, Enrekang botanic garden focus on ornamental and aromatic plant. Many new botanic gardens will help rare plant conservation in Indonesia (Purnomo et al., 2015).

Third, Kew Botanic Garden has the Millenium Seed Bank Project Partnership (MSBP, 2011 to present). The aim of MSBP is to continue safeguarding plant diversity worldwide with a focus on plants most at risk and most useful for the future while addressing global challenges for food security, sustainable energy, loss of biodiversity and climate change (Liu et al., 2018). Seed banking remains a key part of RBG Kew to contribute on target 8 and 9 of GSPC (MSBP conserves propagules primarily from orthodox seed-bearing wild vascular plants. It is the largest ex-situ conservation program in the world, currently involving 96 countries and territories (Liu et al., 2018). Indonesian Botanic Garden is one of them. The ability to store a large diversity of germplasm in a small space at relatively low cost makes seed banking a practical and attractive tool for plant conservation (Liu et al., 2018).

Fourth, Botanical gardens present highly suitable venues for the presentation of agricultural displays and educational programs (Miller et al., 2015). Miller et al., 2015 added botanical garden are the house of useful germplasm for improving existing and future crops. By forming partnerships with appropriate universities and other institutions with active research programs in agriculture, state departments of agriculture, international agricultural organizations, farmer's organizations and industry groups, gardens will be able to improve their ability to present displays and information concerning agriculture. Botanical gardens currently have well-developed programs of plant diversity and conservation research, which can easily be expanded to strengthen sustainable agriculture, address agriculture impacts on natural biodiversity and advance public understanding of both.

\section{DISCUSSION}

\section{The role of the botanic garden}

The botanic garden has many roles. Nowadays the mission of many botanic gardens not only focuses on developing horticulture collections and taxonomic research but has expanded to include their contribution to species and habitat recovery in the wild (Havens et al., 2006). Meanwhile, under Indonesian Presidential Decree number 93: 2011 explained that a botanic garden is an area for exsitu conservation which has documented plant collections. The plant collection arranged based on taxonomical classification, bioregion, thematical pattern or combination from pattern describe before for conservation, research, education, recreation and ecosystem services (Sita and Widyatmoko, 2019; Surya et al., 2013). Miller et al. (2015) mention botanic gardens are living collection repositories of plant biodiversity that cultivate approximately one-third of known plant species globally. Historically, many botanic gardens focused on plants for their utility rather than their aesthetic or diversity value. Until the early twentieth century, food plants and their wild relatives played a significant role in many botanical gardens. This caused prominent scientist to propose that botanic gardens should become a field museum of agriculture (Miller et al., 2015).

The botanic garden also becomes an excellent place to document, conserve and make available wild plant diversity in the service of improving agriculture because botanic garden was the world's primary repository living plant collections. Living plant collection of botanic gardens can make crop varieties and their wild relatives more readily available than in nature, where they may even have become extinct (Miller et al., 2015). Therefore, botanic garden take part in ex situ CWR conservation.

\section{Target 9 of the GSPC}

The Global Strategy for Plant Conservation (GSPC) is a cross-cutting strategy, developed and adopted by the United Nation's Convention on Biological Diversity (CBD) in 2002 (Ren et al., 2019). The GSPC document incorporating social and economic goals therefore provided a useful model on how this target could be transformed into compre- 
hensive, practical and measurable on the ground actions and programmes (Jackson and Kennedy, 2009). One of GSPC target is Target 9. Target 9 calls for $70 \%$ of the genetic diversity of crops including their wild relatives and other socioeconomically valuable plant species conserved, while respecting, preserving and maintaining associated indigenous and local knowledge.

Several institute consist of government and private participate in manage agriculture plant genetic resource consist of 18 institute under ministry of agriculture, ministry of forestry, ministry of research and technology, ministry of health, Indonesian Institute of Science (LIPI), university and private organization such as Taman Buah Mekarsari, Kampung Obat Martha Tilaar, Taman Bunga Nusantara (Widjaja et al., 2014). Plant genetic resources includes landrace, improve cultivar, and crop wild relative (Sutoro, 2008). He stated Agricultural research institutes do exploration activities for collecting indigenous genetic material have been done to protect and save this endangered crop species. Plant character observed mostly such as resistant to pest and disease, drought, iron toxicity and acid soils. This genetic resource is the basis for future progress in developing new varieties.

\section{Barrier to implementation target 9 of GSPC}

Based on a survey conducted by Williams et al. (2012) to 505 botanic garden members of Botanic Garden Conservation International (BGCI) and 124 botanic gardens non-BGCI members show that compares with 16 other targets of GSPC, target 6,9 and 12 which is related to the sustainable use of plant resources and conservation of indigenous knowledge are least implemented. This result support previous research indicating target 6,9 , and 12 which is relating to conservation of socioeconomics species and sustainable use of plants are the least implemented of the GSPC targets (Paton and Lughada 2011). Donaldson (2009) said that the three targets is not considered as traditional activities of the botanic garden which known only considered as conservation and body of knowledge on threatened species. Another botanic garden in the world faces a similar case. Some botanic garden has a weak implementation, less than $15 \%$ respondent has an activity that supports these target (William and Sharrock 2010; William et al., 2012).

Paton and Lughadha (2011) said FAO and IPGRI are institutions that facilitating to achieve target 9. This is clear that some botanic garden also has a different perspective on how to achieve this because of different responsibility. Furthermore, Sharrock et al. (2018) said the major challenge with target 9 is to identify and conserve the many thousands of other species that are of socio-economic importance at the national or local level as well as managing the indigenous knowledge associate with these species. Williams et al. (2012) said another reason for the least implemented target because other institutional and stakeholders are also involved in the implementation of the GSPC at national, regional and international levels. Sabran (2016) added to avoid duplication or overlap of activities, there is a need to delineate the task or activities among those institutions, universities and organizations. Since the absence of the national law governing genetic resources, the delineation might be difficult to be agreed upon. Other reason also because of limited funding to the implementation of the GSPC targets, William et al. (2012) gave a solution to increase communication between the GSPC policy actors and additional financial support (William et al., 2012; Liu et al., 2018).

\section{Success story to achieve target 9 by another Bo- tanic garden.}

Botanic garden in agricultural biodiversityrich regions is uniquely poised to help conserve regionally important foods in partnerships with local communities (Krishnan et al., 2019). Target 9 focuses on crops, their wild relatives and other socio-economically important species, especially local importance product. This target can be achieved by working with local communities. There are two example CWR collection in botanic garden such as the collection of breadfruits at $\mathrm{Na}$ tional Tropical Botanical Garden in Hawaii, and the collection of native and domesticated apples grown by the Almaty Botanical Garden in Kazakhstan (Miller et al., 2015)

Botanical garden also play role to disseminate information on biodiversity conservation and sus- 
tainable use of plants to students and the general population. In Mexico there are three botanic garden considered as ethnobotanical (i.e. link wild and semidomesticated species to human uses) (Gonzales and Cadena, 2018). However, a good example of collaboration between the botanic garden and other institutions is shown in Washington DC's United State Botanic Garden (USBG) exhibit celebrating wheat (Triticum aestivum L.) and the effort of American wheat breeder Norman Borlaug. This exhibition involves collaboration from agricultural researchers. This exhibition tells about the breeding history of Bourlag's Mexico-based breeding program. The garden grew six main commercial classes of modern wheat alongside ancient wheats, Researchers at Cornell University provided seeds to grow the ancient wheats, while the USDA national small grains collection in Aberdeen provided the Bourlag varieties. Scientist at USDA in Beltsville, Maryland generously provided their time and facilities for verification and provided valuable agronomic guidance (Krishnan et al., 2019).

\section{CONCLUSION}

Indonesian Botanic Garden show activity related to implementation target 9 of GSPC. In national level, collaboration with another institution and organization have potency to conserve Indonesian food and horticulture crop wild relative. Botanic garden as an ex situ CWR conservation has role to disseminate information on biodiversity conservation and sustainable use of plants to student and the general population.

\section{ACKNOWLEDGEMENT}

The author acknowledges the Ministry of Research, Technology, and Higher Education of Republic Indonesia for the scholarship. The author would thank to Mrs Milena Holmgren from Wageningen University for her comment and guidance during writing this manuscript. The author also thank to Mr Danang for botanic garden development information.

\section{REFERENCE}

Ariati SR, Astuti RS, Supriyatna I, Yuswandi AY, Setiawan A, Saftaningsih D, Pribadi DO. Bogor, 2019. An Alphabetical List of Plant Species Cultivated in the Bogor Botanic Gardens. Center for Plant Conservation Botanical Garden. $376 \mathrm{p}$

Convention on Biological Diversity. 2016. http:/www.cbd.int/ gspc/targets.shtml

Donaldson JS. 2009. Botanic Gardens Science for Conservation and Global Change. Trends in Plant Science 14(11): 1-6

Fielder H, Brotherton P, Hosking J, Hopkins JJ, Ford-Lloyd B, Maxted N. 2015. Enhancing the conservation of crop wild relatives in England. PLoS ONE 10(6):e0130804. https:// doi.org/10.1371/jour nal.pone .0130 804

González, R., \& Cadena, J. 2018. Crop wild relatives in Mexico: An overview of richness, importance, and conservation status. In North American Crop Wild Relatives, Volume 1 (pp. 63-96). Springer, Cham.

Hapsari L, lestari DA, and Masrum A. 2015. Album Koleksi Pisang Kebun Raya Purwodadi Seri I: 2010-2015. UPT Balai Konservasi Tumbuhan Kebun Raya Purwodadi LIPI

Hapsari, L. 2010. Dua dasawarsa koleksi pisang (Musaceae) Kebun Raya Purwodadi (1990-2010). Jurnal Berkala Penelitian Hayati Edisi Khusus A, 5, 147-151.

Havens K, Vitt P, Maunder M, Guerrant EO, Dixon K. 2006. Ex situ plant conservation and beyond. Bioscience 56(6): 525531.

Hird A, Kramer AT. 2013. Achieving target 8 of the Global Strategy for Plant Conservation: Lessons learned from the North American collection's assessment. Ann Missouri Bot Garden. 99: 161-166

Jackson PSW, Sutherland LA. 2000. International Agenda for Botanic Garden in Conservation. Botanic Gardens Conservation International. U.K

Jackson, P. W., \& Kennedy, K. 2009. The global strategy for plant conservation: a challenge and opportunity for the international community. Trends in plant science, 14(11), 578-580.

Krishnan S, Moreau T, Kuehny J, Novy A, Greene SL, Khoury CK. 2019. Resetting the table for people and plants: Botanic gardens and research organizations collaborate to address food and agricultural plant blindness. Plants, People, Planet 1(3), 157-163.

Liu U, Breman E, Cossu TA, Kenney S. 2018. The conservation value of germplasm stored at the Millenium Seed Bank Royal Botanic Garden Kew UK. Biodivers Conserv 27: 1347-1386

Miller AJ, Novy A, Glover J, Kellogg EA, Maul JE, Raven P, Jackson PW. 2015. Expanding the role of botanical gardens in the future of food. Nature Plants, 1(6), 1-4.

Myers N, Mittermeier RA, Mittermeier CG, da Fonseca GAB, Kent J. 2000. Biodiversity Hotspots for Conservation Priorities. Nature vol 403(2): 853-858

Narko D, Suprapto A, Lestarini W. 2012. An Alphabetical List of Plant Species Cultivated in the Purwodadi Botanic Gardens. Purwodadi Botanic Garden. 
Paton A, Lughadha N. 2011. The Irresistible Target Meets the unachievable Objective. What have Eight Years of GSPC Implementation Taught us about Target Setting and Achievable Objectives? Bot J Linn Soc 166.250-260

Plant Registation Unit. 2020. The Number of Plant Living Collection and Herbarium in July 2020 (Monthly report, unpublished). Tabanan. Bali Botanic Garden.

Purnomo DW, Magandhi M, Kuswantoro F, Risna RA, Witono JR. 2015. Pengembangan koleksi tumbuhan kebun raya daerah dalam kerangka strategi konservasi tumbuhan di Indonesia. Buletin Kebun Raya vol 18(2): 111-124

Rahman W, Brehm JM, Maxted N. 2019. Setting conservation priorities for the wild relatives of food crops in Indonesia. Genet Resour Crop Evol 66(4), 809-824.

Ren, H., Qin, H., Ouyang, Z., Wen, X., Jin, X., Liu, H., ... \& Smith, P. 2019. Progress of implementation on the Global Strategy for Plant Conservation in (2011-2020) China. Biological Conservation, 230, 169-178.

Schaal B. 2019. Plants and people: Our shared history and future. Plants, People, Planet 1(1), 14-19. https :// doi.org/10.1002/ppp3.12

Sharrock S, Hoft R, Dias BFDS. 2018. An overview of recent progress in the implementation of the Global Strategy for Plant Conservation-a global perspective. Rodriguésia 69 (4), 1489-1511.

Sharrock S. 2013. Botanic gardens and food security-the results of BGCI's survey. BGJournal, 10(2), 3-7.

Sujarwo W, Gumilang AR, Hidayat IM. 2019. List of living Plants Collections cultivated in Cibodas Botanic Garden. Cibodas Botanic Garden.

Surya MI, Lalilati M, Ekasari I, Nuraleni Y, Astutik S, Normasiwi S, Gumilang AR, Junaedi DI, Mutaqien Z, Nurdiana DR, Rahman W, Destri, Rozak AH. 2013. Konservasi Tumbuhan di Kebun Raya Cibodas sebagai Penyelamat Keanekaragaman Hayati Pegunungan di Indonesia. Lokakarya Nasional "Keanekaragaman Hayati sebagai Modal Dasar Pembangunan”.

Sutoro. 2008. Plant Genetic Resource Management in Indonesia. In Capacity Building for Development and Implementation of Risk Management Systems on Genetic Resources: proceedings of the APEC-ATCWG Workshop, Taichung, Chinese Taipei, October 14-17 (pp. 127-134).

Trimanto, Hapsari L. 2015. Diversity and Utilization of Dioscorea spp. tuber as alternative food source in Nganjuk Regency, East Java. Agrivita 37(2): 98-107

Ulian T, Pritchard HW, Cocker CP, Mattana E. 2019. Enhancing Food Security through Seed Banking and Use of Wild Plants: Case Studies from the Royal Botanic Gardens, Kew. Encyclopedia of Food Security and Sustainability. Vol 3. https://doi.org/10.1016/B978-0-08-100596-5.22019 $-2$
Widjaja EA, Rahayuningsih Y, Rahajoe JS, Ubaidillah R, Maryanto I, Walojo EB, Semiadi G, editors. Kekinian Keanekaragaman Hayati Indonesia 2014. Jakarta: LIPI Press; 2014.

Widyatmoko D, Rosniati RA. 2017. A Role of Indonesian Botanic Gardens in Achieving Global Strategy for Plant Conservations Goals. Annals of The Missouri Botanical Garden. 102: 377-385

Williams S, Sharrock S. 2010. Botanic gardens and their response to the global strategy for Plant conservation. $B G$ Journal 7: 3-7

Williams SJ, Jones JPG, Clubbe C, Sharrock S, Gibbons JM 2012. Why are some Biodiversity Implemented and others Ignored? Lesson from the Uptake of the Global Strategy for Plant Conservation by Botanic Garden. Biodivers Conserv 21: 175-187.

Kusmana, C., \& Hikmat, A. (2015). Keanekaragaman hayati flora di Indonesia. Journal of Natural Resources and Environmental Management, 5(2), 187-187.

Bidang Pengembangan Kawasan Kebun Raya (PK2R). 2019. Laporan Perkembangan Pembangunan Kebun Raya Daerah di Indonesia. Pusat Penelitian Konservasi Tumbuhan dan Kebun Raya LIPI

Sabran, M. 2016. Plant Genetic Resources Management in Indonesia: Conservation, Uses, and Policy in Proceedings Prebreeding and Gene Recovery for Food and Renewable Energy Security. Indonesian Agency for Agricultural Research and Development. Jakarta

Butler RA (2016) The top 10 most biodiverse countries. What are the world's most biodiverse countries?. https://news. mongabay.com/2016/05/top-10-biodiverse-countries. (Accessed on 15 April 2020)

HUi-Lin, L. The origin of cultivated plants in Southeast Asia. Econ Bot 24, 3-19 (1970). https://doi.org/10.1007/ BF02860628

Ariati, SR and Wdyatmoko, D. 2019. Botanic Garden Profile: Bogor Botanic Garden. SIBBALDIA. The Journal of Botanic Garden Horticulture No. 17 


\section{Pedoman Penulisan Naskah Berita Biologi}

Berita Biologi adalah jurnal yang menerbitkan artikel kemajuan penelitian di bidang biologi dan ilmu-ilmu terkait di Indonesia. Berita Biologi memuat karya tulis ilmiah asli berupa makalah hasil penelitian, komunikasi pendek dan tinjauan kembali yang belum pernah diterbitkan atau tidak sedang dikirim ke media lain. Masalah yang diliput harus menampilkan aspek atau informasi baru.

\section{Tipe naskah}

1. Makalah lengkap hasil penelitian (original paper)

Naskah merupakan hasil penelitian sendiri yang mengangkat topik yang up to date. Tidak lebih dari 15 halaman termasuk tabel dan gambar. Pencantuman lampiran seperlunya, namun redaksi berhak mengurangi atau meniadakan lampiran.

2. Komunikasi pendek (short communication)

Komuniasi pendek merupakan makalah hasil penelitian yang ingin dipublikasikan secara cepat karena hasil termuan yang menarik, spesifik dan atau baru, agar dapat segera diketahui oleh umum. Hasil dan pembahasan dapat digabung.

3. Tinjauan kembali (review)

Tinjauan kembali merupakan rangkuman tinjauan ilmiah yang sistematis-kritis secara ringkas namun mendalam terhadap topik penelitian tertentu. Hal yang ditinjau meliputi segala sesuatu yang relevan terhadap topik tinjauan yang memberikan gambaran 'state of the art', meliputi temuan awal, kemajuan hingga issue terkini, termasuk perdebatan dan kesenjangan yang ada dalam topik yang dibahas. Tinjauan ulang ini harus merangkum minimal 30 artikel.

\section{Struktur naskah}

1. Bahasa

Bahasa yang digunakan adalah Bahasa Indonesia atau Inggris yang baik dan benar.

2. Judul

Judul diberikan dalam bahasa Indonesia dan inggris. Judul ditulis dalam huruf tegak kecuali untuk nama ilmiah yang menggunakan bahasa latin, Judul harus singkat, jelas dan mencerminkan isi naskah dengan diikuti oleh nama serta alamat surat menyurat penulis dan alamat email. Nama penulis untuk korespondensi diberi tanda amplop cetak atas (superscript). Jika penulis lebih dari satu orang bagi pejabat fungsional penelitian, pengembangan agar menentukan status sebagai kontributor utama melalui penandaan simbol dan keterangan sebagai kontributor utama dicatatan kaki di halaman pertama artikel.

3. Abstrak

Abstrak dibuat dalam dua bahasa, bahasa Indonesia dan Inggris. Abstrak memuat secara singkat tentang latar belakang, tujuan, metode, hasil yang signifikan, kesimpulan dan implikasi hasil penelitian. Abstrak berisi maksimum 200 kata, spasi tunggal. Di bawah abstrak dicantumkan kata kunci yang terdiri atas maksimum enam kata, dimana kata pertama adalah yang terpenting. Abstrak dalam Bahasa Inggris merupakan terjemahan dari Bahasa Indonesia. Editor berhak untuk mengedit abstrak demi alasan kejelasan isi abstrak.

4. Pendahuluan

Pendahuluan berisi latar belakang, permasalahan dan tujuan penelitian. Perlu disebutkan juga studi terdahulu yang pernah dilakukan terkait dengan penelitian yang dilakukan.

5. Bahan dan cara kerja

Bahan dan cara kerja berisi informasi mengenai metode yang digunakan dalam penelitian. Pada bagian ini boleh dibuat sub-judul yang sesuai dengan tahapan penelitian. Metoda harus dipaparkan dengan jelas sesuai dengan standar topik penelitian dan dapat diulang oleh peneliti lain. Apabila metoda yang digunakan adalah metoda yang sudah baku cukup ditulis sitasinya dan apabila ada modifikasi maka harus dituliskan dengan jelas bagian mana dan hal apa yang dimodifikasi.

6. Hasil

Hasil memuat data ataupun informasi utama yang diperoleh berdasarkan metoda yang digunakan. Apabila ingin mengacu pada suatu tabel/ grafik/diagram atau gambar, maka hasil yang terdapat pada bagian tersebut dapat diuraikan dengan jelas dengan tidak menggunakan kalimat 'Lihat Tabel 1'. Apabila menggunakan nilai rata- rata maka harus menyertakan pula standar deviasinya.

7. Pembahasan

Pembahasan bukan merupakan pengulangan dari hasil. Pembahasan mengungkap alasan didapatkannya hasil dan arti atau makna dari hasil yang didapat tersebut. Bila memungkinkan, hasil penelitian ini dapat dibandingkan dengan studi terdahulu.

8. Kesimpulan

Kesimpulan berisi infomasi yang menyimpulkan hasil penelitian, sesuai dengan tujuan penelitian, implikasi dari hasil penelitian dan penelitian berikutnya yang bisa dilakukan.

9. Ucapan terima kasih

Bagian ini berisi ucapan terima kasih kepada suatu instansi jika penelitian ini didanai atau didukungan oleh instansi tersebut, ataupun kepada pihak yang membantu langsung penelitian atau penulisan artikel ini.

10. Daftar pustaka

Tidak diperkenankan untuk mensitasi artikel yang tidak melalui proses peer review. Apabila harus menyitir dari "laporan" atau "komunikasi personal" dituliskan 'unpublished' dan tidak perlu ditampilkan di daftar pustaka. Daftar pustaka harus berisi informasi yang up to date yang sebagian besar berasal dari original papers dan penulisan terbitan berkala ilmiah (nama jurnal) tidak disingkat.

\section{Format naskah}

1. Naskah diketik dengan menggunakan program Microsoft Word, huruf New Times Roman ukuran 12, spasi ganda kecuali Abstrak spasi tunggal. Batas kiri-kanan atas-bawah masing-masing 2,5 cm. Maksimum isi naskah 15 halaman termasuk ilustrasi dan tabel.

2. Penulisan bilangan pecahan dengan koma mengikuti bahasa yang ditulis menggunakan dua angka desimal di belakang koma. Apabila menggunakan Bahasa Indonesia, angka desimal ditulis dengan menggunakan koma (,) dan ditulis dengan menggunakan titik (.) bila menggunakan bahasa Inggris. Contoh: Panjang buku adalah $2,5 \mathrm{~cm}$. Lenght of the book is $2.5 \mathrm{~cm}$. Penulisan angka 1-9 ditulis dalam kata kecuali bila bilangan satuan ukur, sedangkan angka 10 dan seterusnya ditulis dengan angka. Contoh lima orang siswa, panjang buku $5 \mathrm{~cm}$.

3. Penulisan satuan mengikuti aturan international system of units.

4. Nama takson dan kategori taksonomi ditulis dengan merujuk kepada aturan standar yang diakui. Untuk tumbuhan menggunakan International Code of Botanical Nomenclature (ICBN), untuk hewan menggunakan International Code of Zoological Nomenclature (ICZN), untuk jamur International Code of Nomenclature for Algae, Fungi and Plant (ICFAFP), International Code of Nomenclature of Bacteria (ICNB), dan untuk organisme yang lain merujuk pada kesepakatan Internasional. Penulisan nama takson lengkap dengan nama author hanya dilakukan pada bagian deskripsi takson, misalnya pada naskah taksonomi. Penulisan nama takson untuk bidang lainnya tidak perlu menggunakan nama author.

5. Tata nama di bidang genetika dan kimia merujuk kepada aturan baku terbaru yang berlaku. 
6. Untuk range angka menggunakan en dash (-), contohnya pp.1565-1569, jumlah anakan berkisar 7-8 ekor. Untuk penggabungan kata menggunakan hyphen (-), contohnya: masing-masing.

7. Ilustrasi dapat berupa foto (hitam putih atau berwarna) atau gambar tangan (line drawing).

8. Tabel

Tabel diberi judul yang singkat dan jelas, spasi tunggal dalam bahasa Indonesia dan Inggris, sehingga Tabel dapat berdiri sendiri. Tabel diberi nomor urut sesuai dengan keterangan dalam teks. Keterangan Tabel diletakkan di bawah Tabel. Tabel tidak dibuat tertutup dengan garis vertikal, hanya menggunakan garis horisontal yang memisahkan judul dan batas bawah.

9. Gambar

Gambar bisa berupa foto, grafik, diagram dan peta. Judul gambar ditulis secara singkat dan jelas, spasi tunggal. Keterangan yang menyertai gambar harus dapat berdiri sendiri, ditulis dalam bahasa Indonesia dan Inggris. Gambar dikirim dalam bentuk .jpeg dengan resolusi minimal 300 dpi, untuk line drawing minimal 600dpi.

10. Daftar Pustaka

Sitasi dalam naskah adalah nama penulis dan tahun. Bila penulis lebih dari satu menggunakan kata 'dan' atau et al. Contoh: (Kramer, 1983), (Hamzah dan Yusuf, 1995), (Premachandra et al., 1992). Bila naskah ditulis dalam bahasa Inggris yang menggunakan sitasi 2 orang penulis maka digunakan kata 'and'. Contoh: (Hamzah and Yusuf, 1995). Jika sitasi beruntun maka dimulai dari tahun yang paling tua, jika tahun sama maka dari nama penulis sesuai urutan abjad. Contoh: (Anderson, 2000; Agusta et al., 2005; Danar, 2005). Penulisan daftar pustaka, sebagai berikut:

a. Jurnal

Nama jurnal ditulis lengkap.

Agusta, A., Maehara, S., Ohashi, K., Simanjuntak, P. and Shibuya, H., 2005. Stereoselective oxidation at C-4 of flavans by the endophytic fungus Diaporthe sp. isolated from a tea plant. Chemical and Pharmaceutical Bulletin, 53(12), pp.1565-1569.

b. Buku

Anderson, R.C. 2000. Nematode Parasites of Vertebrates, Their Development and Tramsmission. 2nd ed. CABI Publishing. New York. pp. 650 .

c. Prosiding atau hasil Simposium/Seminar/Lokakarya.

Kurata, H., El-Samad, H., Yi, T.M., Khammash, M. and Doyle, J., 2001. Feedback Regulation of the Heat Shock Response in Eschericia coli. Proceedings of the 40th IEEE Conference on Decision and Control. Orlando, USA. pp. 837-842.

d. Makalah sebagai bagian dari buku

Sausan, D., 2014. Keanekaragaman Jamur di Hutan Kabungolor, Tau Lumbis Kabupaten Nunukan, Kalimanan Utara. Dalam: Irham, M. \& Dewi, K. eds. Keanekaraman Hayati di Beranda Negeri. pp. 47-58. PT. Eaststar Adhi Citra. Jakarta.

e. Thesis, skripsi dan disertasi

Sundari, S., 2012. Soil Respiration and Dissolved Organic Carbon Efflux in Tropical Peatlands. Dissertation. Graduate School of Agriculture. Hokkaido University. Sapporo. Japan.

f. Artikel online.

Artikel yang diunduh secara online ditulis dengan mengikuti format yang berlaku untuk jurnal, buku ataupun thesis dengan dilengkapi alamat situs dan waktu mengunduh. Tidak diperkenankan untuk mensitasi artikel yang tidak melalui proses peer review misalnya laporan perjalanan maupun artikel dari laman web yang tidak bisa dipertangung jawabkan kebenarannya seperti wikipedia.

Himman, L.M., 2002. A Moral Change: Business Ethics After Enron. San Diego University Publication. http:ethics.sandiego.edu/LMH/ oped/Enron/index.asp. (accessed 27 Januari 2008) bila naskah ditulis dalam bahasa inggris atau (diakses 27 Januari 2008) bila naskah ditulis dalam bahasa indonesia

\section{Formulir persetujuan hak alih terbit dan keaslian naskah}

Setiap penulis yang mengajukan naskahnya ke redaksi Berita Biologi akan diminta untuk menandatangani lembar persetujuan yang berisi hak alih terbit naskah termasuk hak untuk memperbanyak artikel dalam berbagai bentuk kepada penerbit Berita Biologi. Sedangkan penulis tetap berhak untuk menyebarkan edisi cetak dan elektronik untuk kepentingan penelitian dan pendidikan. Formulir itu juga berisi pernyataan keaslian naskah yang menyebutkan bahwa naskah adalah hasil penelitian asli, belum pernah dan tidak sedang diterbitkan di tempat lain serta bebas dari konflik kepentingan

\section{Penelitian yang melibatkan hewan dan manusia}

Setiap naskah yang penelitiannya melibatkan hewan (terutama mamalia) dan manusia sebagai obyek percobaan/penelitian, wajib menyertakan 'ethical clearance approval' yang dikeluarkan oleh badan atau pihak berwenang.

\section{Lembar ilustrasi sampul}

Gambar ilustrasi yang terdapat di sampul jurnal Berita Biologi berasal dari salah satu naskah yang dipublikasi pada edisi tersebut. Oleh karena itu, setiap naskah yang ada ilustrasinya diharapkan dapat mengirimkan ilustrasi atau foto dengan kualitas gambar yang baik dengan disertai keterangan singkat ilustrasi atau foto dan nama pembuat ilustrasi atau pembuat foto.

Proofs

Naskah proofs akan dikirim ke penulis dan penulis diwajibkan untuk membaca dan memeriksa kembali isi naskah dengan teliti. Naskah proofs harus dikirim kembali ke redaksi dalam waktu tiga hari kerja.

\section{Pengiriman naskah}

Naskah dikirim secara online ke website berita biologi: http://e-journal.biologi.lipi.go.id/index.php/berita_biologi

\section{Alamat kontak}

Redaksi Jurnal Berita Biologi, Pusat Penelitian Biologi-LIPI

Cibinong Science Centre, Jl. Raya Bogor Km. 46 Cibinong 16911

Telp: +61-21-8765067, Fax: +62-21-87907612, 8765063, 8765066,

Email: berita.biologi@mail.lipi.go.id

jurnalberitabiologi@yahoo.co.id atau

jurnalberitabiologi@gmail.com 


\section{BERITA BIOLOGI}

Vol. 20

Isi (Content)

April 2021

P-ISSN 0126-1754

E-ISSN 2337-8751

TINJAUAN ULANG (Review)

GLIKOBIOLOGI, GLIKANS DAN GLIKOPROTEIN BESERTA APLIKASINYA DALAM KESEHATAN

[Glycobiology, glycans and glycoprotein with its applications in health]

Adi Santoso

ARTIKEL

KEANEKARAGAMAN DAN KOMPOSISI SPESIES MAKROALGA LAUT PADA TIPOLOGI PANTAI YANG BERBEDA DI KAWASAN PESISIR GUNUNGKIDUL D.I. YOGYAKARTA

[Species Diversity and Composition of Marine Macroalgae on Different Coastal Typology in Gunungkidul D.I. Yogyakarta]

Dwi Sartika, Abdul Razaq Chasani, Ajeng Meidya N, Septi Lutfiatun N, dan Septy Wulan C.

PENGARUH MINYAK ATSIRI DAUN JERUK PURUT (Citrus hystrix) TERHADAP DINDING SEL BAKTERI

Staphylococcus aureus

[The Effect of Kaffir Lime Leaf Essential Oil (Citrus hystrix) in Bacterial Cell Walls Staphylococcus aureus]

Opstaria Saptarini dan Ismi Rahmawati...

COMPOSITION AND QUANTIFICATION OF FATTY ACIDS PRODUCED BY Xylaria sp. DAP KRI-5

[Komposisi dan Kuantifikasi Asam Lemak yang Diproduksi oleh Jamur Endofit Xylaria sp. DAP KRI-5]

Ahmad Fathoni, Muhammad Ilyas, Praptiwi, Andi Saptaji Kamal, Lukman Hafid, Lina Marlina, Andria Agusta

PROGRESS IMPLEMENTATION OF TARGET 9 OF GLOBAL STRATEGY FOR PLANT CONSERVATION CONDUCTED BY INDONESIAN BOTANIC GARDEN NETWORK

[Pelaksanaan Kemajuan target 9 Strategy Global untuk Konservasi Tumbuhan yang di Lakukan Jaringan Taman Botani Indonesia] Siti Fatimah Hanum

STUDI POTENSI TANAMAN TEBU IRENG (Saccharum officinarum L.) SEBAGAI ANTIOKSIDAN DAN

\section{ANTIBAKTERI}

[Potential Study of Ireng Cane (Saccharum officinarum L.) as Antioxidant, Antidiabetic and Antibacterial]

I Putu Agus Hendra Wibawa, Putri Sri Andila, I Nyoman Lugrayasa, dan Wawan Sujarwo....

ASPEK BIOLOGIS IKAN EKOR PEDANG (Xiphophorus hellerii HECKEL, 1848) DI CATUR DANAU BALI

[Biological Aspects of Green Swordtail (Xiphophorus hellerii Heckel, 1848) at Catur Danau Bali]

I Nyoman Y. Parawangsa, Prawira A. R. P. Tampubolon dan Nyoman Dati Pertami

KAJIAN AWAL POTENSI OPOSUM LAYANG (Petaurus breviceps) SEBAGAI RESERVOIR BAKTERI ZOONOTIK DAN RESISTENSI ANTIMIKROBA

[Preliminary Study of Potential Sugar Glider (Petaurus breviceps) as Reservoir of Zoonotic Bacteria and Antimicrobial Resistance] Rifka A. N. Safitri1, Sarsa A. Nisa, Nurul Inayah, Taufiq P. Nugraha, Agung Suprihadi1, Sri Pujiyanto, Anang S. Achmadi, Achirul Nditasari, Sugiyono Saputra

EKSPRESI Hsa-miR-22-3p PADA URIN PASIEN BENIGN PROSTATE HYPERPLASIA (BPH) SEBAGAI BIOMARKER NON INVASIF

[Expression of Hsa-miR-22-3p on Urin Patients Benign Prostate Hyperplasia (BPH) as Biomarker Non Invasive]

Angga Dwi Prasetyo, Santosa Pradana Putra Setya Negara, Richardus Hugo Sertia Putra, Joni Kristanto, R. Danarto, Sofia Mubarika Haryana, Indwiani Astuti

THE EFFECT OF CHROMIUM STRESS ON MICRO-ANATOMICAL PROFILE OF CHILI (Capsicum annuUm L.) [Efek Cekaman Kromium Terhadap Profil Mikro-anatomi Cabai (Capsicum annuum L.)]

Siti Samiyarsih, Dede Winda Nur Fauziah, Sri Lestari, Nur Fitrianto .

CHARACTERIZATION OF SUPERNATANT EXTRACT AND VIABILITY OF BACILLUS SUBTILIS KM16 AND PSEUDOMONAS SPP. IN FISH FEED AS BIOCONTROL AGENTS AGAINST AQUACULTURE PATHOGENS [Karakterisasi Ekstrak Supernatan dan Viabilitas Bacillus subtilis KM16 dan Pseudomonas spp., di Dalam Pakan Ikan Sebagai Agen Biokontrol terhadap Patogen Akuakultur]

Stella Magdalena, Brenda Kristanti, Yogiara

PEMBARUAN TAKSONOMI, SEBARAN SPESIES DAN KUNCI IDENTIFIKASI NYAMUK DEWASA TRIBE FICALBIINI (DIPTERA: CULICIDAE) DI INDONESIA

[An update on taxonomic, species distribution, and identification key for mosquitoes of the tribe Ficalbiini (Diptera: Culicidae) in Indonesia]

Sidiq Setyo Nugroho

\section{SHORT COMMUNICATION}

KERAGAMAN LUMUT KERAK PADA TANAMAN TEH (Camellia sinensis (L.) Kuntze) DI PERKEBUNAN TEH PT SARANA MANDIRI MUKTI KABUPATEN KEPAHIANG PROVINSI BENGKULU

[Diversity of Lichens at Tea Plants (Camellia sinensis (L.) Kuntze) at PT. Sarana Mandiri Mukti Tea Plantation of Kepahiang Regency Bengkulu Province]

Rochmah Supriati, Helmiyetti, Dwi Agustian 